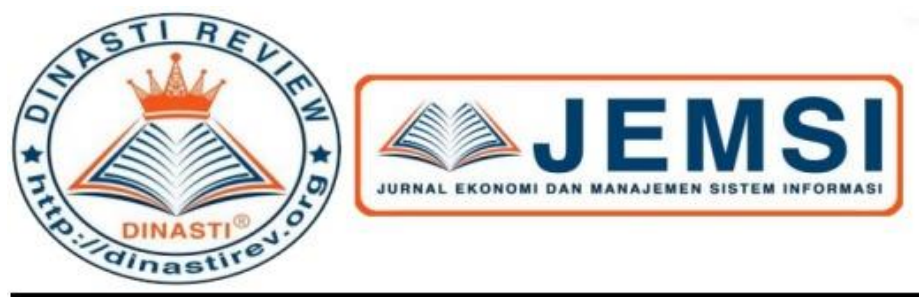

+62 878-9658-6407

087896586407 ()

https://dinastirev.org/JEMSI (-)

editor@dinastirev.org (G.

\title{
PENGARUH PENGETAHUAN WAJIB PAJAK TENTANG PERPAJAKAN TERHADAP KEPATUHAN WAJIB PAJAK MEMBAYAR PAJAK KENDARAAN BERMOTOR
}

\section{Edwin ${ }^{1}$, Mardalena ${ }^{2}$}

1) Alumni Program Studi Pendidikan Ekonomi STKIP YPM, Jambi

${ }^{2)}$ Dosen Program Studi Pendidikan Ekonomi STKIP YPM, Jambi

ARTICLE INFORMATION

Received: 01 September 2019

Revised: 11 September 2019

Issued: 21 September 2019

Corresponding author: first author E-mail:

mardalena@stkipypmbangko.ac.id

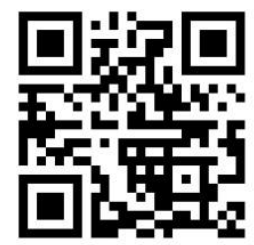

DOI:10.31933/JEMSI
Abstrak: Salah satu jenis pajak daerah adalah pajak kendaraan bermotor. Subjek pajak kendaraan bermotor adalah orang pribadi atau badan yang memiliki dan menguasai kendaraan bermotor. Kepatuhan masyarakat untuk membayar pajak kendaraan bermotor didukung pula oleh tingkat pengetahuan masyarakat itu sendiri. Oleh karena itu, penelitian ini dilakukan dengan tujuan untuk mengetahui ada tidaknya pengaruh pengetahuan wajib pajak tentang perpajakan terhadap kepatuhan wajib pajak membayar pajak kendaraan bermotor di desa Rantau Alai khususnya dusun Tanjung di tahun 2017. Metode yang digunakan dalam penelitian ini adalah metode kuantitatif korelasional, yaitu untuk mengetahui seberapa jauh pengaruh atau hubungan antara variabel $\mathrm{X}$ terhadap variabel $\mathrm{Y}$ berdasarkan koefisien dan korelasi. Sampel yang diteliti pada penelitian ini sebanyak 90 orang. Teknik pengumpulan data dalam penelitian ini terdiri dari dua jenis, yakni data primer yaitu menggunakan angket, dan data sekunder yaitu dokumentasi. Dari hasil analisa data pada penelitian ini, diketahui bahwa hasil uji $\mathrm{t}$ diperoleh nilai nilai sig $0,043 \leq 0,05$, maka peneliti menyimpulkan bahwa hipotesis pada penelitian ini telah terjawab, yakni Ho ditolak, Ha diterima. Hal ini berarti bahwa terdapat pengaruh yang signifikan antara pengetahuan wajib pajak terhadap kepatuhan wajib pajak membayar pajak kendaraan bermotor di desa Rantau Alai khususnya dusun Tanjung tahun 2017. Berdasarkan hasil penelitian ini peneliti menyarankan kepada pemerintah daerah agar semakin meningkatkan kesadaran masyarakat untuk membayar pajak kendaraan bermotor dengan cara memberikan edukasi atau mensosialisasikan kepada masyarakat manfaat dan fungsi dari membayar pajak kendaraan 
bermotor.

Kata Kunci: Pengaruh, Pengetahuan, Kepatuhan, Wajib Pajak Kendaraan Bermotor.

\section{PENDAHULUAN}

Pajak merupakan sumber penerimaan utama negara yang digunakan untuk membiayai pengeluaran pemerintah dan pembangunan, terutama di daerah. Penerimaan pajak di daerah ini menjadi salah satu sumber pendapatan asli daerah. Salah satu jenis pajak daerah adalah pajak kendaraan bermotor. Subjek pajak kendaraan bermotor adalah orang pribadi atau badan yang memiliki dan menguasai kendaraan bermotor. Pembayaran Pajak Kendaraan Bermotor dilakukan di kantor Sistem Administrasi Manunggal Satu Atap (SAMSAT). Dengan demikian, diharapkan peranan Kantor SAMSAT dalam proses pemungutan pajak Kendaraan Bermotor dapat maksimal sehingga berkontribusi positif dalam meningkatkan pendapatan asli daerah. Tingkat pembayaran pajak yang dilakukan oleh wajib pajak menunjukkan tingkat kepatuhan wajib pajak terhadap penaatan peraturan per undang-undangan tentang pajak.

Sulistiyono mengemukakan bahwa kepatuhan merupakan sebuah sikap yang rela untuk melakukan segala sesuatu, yang didasari kesadaran maupun adanya paksaan, yang membuat perilaku seseorang dapat sesuai dengan yang diharapkan (2012: 6). Kepatuhan wajib pajak juga dapat diartikan bahwa wajib pajak mempunyai kesediaan untuk memenuhi kewajiban pajakannya sesuai dengan peraturan yang berlaku tanpa perlu diadakan pemeriksaan, investigasi seksama, peringatan, ataupun ancaman dan penerapan sanksi baik hukum maupun administrasi. Kepatuhan perpajakan didefinisikan sebagai suatu keadaan dimana Wajib Pajak memenuhi semua kewajiban perpajakan dan melaksanakan hak dan perpajakannya.

Sehubungan dengan kepatuhan membayar pajak kendaraan bermotor pada penelitian ini, maka indikator kepatuhan membayar pajak kendaraan bermotor antara lain; (1) mengisi surat pajak kendaraan bermotor yang berisi nama dan alamat lengkap pemilik dan merk atau tipe kendaraan, (2) melaporkan pajak kendaraan bermotor, dan (3) melunasi pajak kendaraan bermotor sesuai dengan tempo yang telah ditentukan.

Dari penjelasan tersebut dapat disimpulkan bahwa kepatuhan wajib pajak adalah suatu keadaan dimana wajib pajak memenuhi semua kewajiban perpajakan dan melaksanakan hak perpajakannya tanpa perlu diadakan pemeriksaan, investigasi seksama, peringatan, ataupun ancaman dan penerapan sanksi baik hukum maupun administrasi.

Kepatuhan membayar pajak tentu di dasari pula oleh pengetahuan si wajib pajak itu sendiri. Pengetahuan berarti segala sesuatu yang diketahui; kepandaian; atau segala sesuatu yang diketahui berkenaan dengan hal (mata pelajaran). Kaitannya dengan perpajakan, pengetahuan adalah segala susuatu yang diketahui mengenai ketentuan umum perpajakan. Pengetahuan tersebut berupa pengetahuan mengenai peraturan perpajakan, pengetahuan mengenai tata cara menghitung maupun melaporkan kewajiban perpajakan, serta pengetahuan tentang fungsi dan peranan pajak. Berdasarkan hal tersebut, pengetahuan memberikan faktor yang penting bagi seseorang untuk melakukan sesuatu, termasuk didalamnya membayar pajak kendaraan bermotor. Oleh karena itu, peneliti merasa perlu untuk mengetahui pengaruh pengetahuan seseorang terhadap kepatuhannya membayar pajak kendaraan bermotor di Desa Rantau Alai khususnya Dusun Tanjung.

Pengetahuan adalah berbagai gejala yang ditemui dan diperoleh manusia melalui pengamatan akal. Pengetahuan muncul ketika seseorang menggunakan akal budinya untuk mengenali benda atau kejadian tertentu yang belum pernah dilihat atau dirasakan 
sebelumnya. Menurut Damajanti (2015: 18-19), pengetahuan adalah informasi yang telah dikombinasikan dengan pemahaman dan potensi untuk menindaki; yang melekat di benak seseorang. Pada umumnya, pengetahuan memiliki kemampuan prediktif terhadap sesuatu sebagai hasil pengenalan atas suatu pola. Manakala informasi dan data sekedar berkemampuan untuk menginformasikan atau bahkan menimbulkan kebingungan, maka pengetahuan berkemampuan untuk mengarahkan tindakan. Ini lah yang disebut potensi untuk menindaki.

Pengetahuan pajak adalah informasi pajak yang dapat digunakan Wajib Pajak sebagai dasar untuk bertindak, mengambil keputusan, dan untuk menempuh arah atau strategi tertentu sehubungan dengan pelaksanaan hak dan kewajibannya di bidang perpajakan. Indikator dari pengetahuan pajak itu sendiri menurut Nur Hidayati (dalam Fermatasari, 2015:3) terdiri dari:

1) Pengetahuan mengenai batas waktu pembayaran dan pelaporan.

2) Pengetahuan mengenai ketentuan umum dan tata cara perpajakan.

3) Pengetahuan mengenai sistem perpajakan.

Berdasarkan uraian tersebut dapat peneliti simpulkan bahwa pengetahuan perpajakan adalah pengetahuan mengenai peraturan perpajakan dalam sistem perpajakan, yang mengubah sikap dan tata laku seorang wajib pajak atau kelompok wajib pajak dalam usaha mendewasakan manusia melalui upaya pengajaran dan pelatihan. Pengetahuan perpajakan ini termasuk jenis pengetahuan rasional.

Mustaqiem mengemukakan bahwa kendaraan bermotor ialah semua kendaraan berroda dua atau lebih beserta gandengannya yang digunakan diseluruh jenis jalan darat dan digerakkan oleh alat yang disebut dengan motor yang dapat mengubah energi menjadi tenaga gerak. Objek pajaknya adalah kepemilikian dan/atau penguasaan kendaraan bermotor (2008:208).

Selanjutnya, dibunyikan dalam Peraturan Daerah Pemerintah Nomor 1 Tahun 2002, Pasal 24 ayat (1) "setiap wajib pajak diwajibkan mengisi Surat Pemberitahuan Pajak Daerah (SPTPD) atau dokumen lain yang dipersamakan, sekurang-kurangnya memuat: (1) nama dan alamat lengkap pemilik, (2) jenis, merk, tipe, isi cylinder, tahun pembuatan, warna, nomor rangka, dan nomor mesin, (3) gandengan dan jumlah sumbu. Selain itu, dasar yuridis penggunaan official assessment system menetapkan bahwa Penghitungan dasar pengenaan Pajak Kendaraan Bermotor sebagaimana tersebut ayat (1) pasal ini, ditetapkan oleh Gubernur sesuai tabel yang ditetapkan oleh Menteri.

Dari penjelasan di atas peneliti menyimpulkan bahwa pajak kendaraan bermotor adalah pajak yang dikenakan kepada orang pribadi atau badan yang memiliki dan menguasai kendaraan bermotor. Tarif pajaknya tergantung jenis kendaraan bermotor yang dimiliki oleh orang tersebut.

Tujuan penelitian ini yaitu untuk mengetahui ada tidaknya pengaruh pengetahuan wajib pajak tentang perpajakan terhadap kepatuhan wajib pajak membayar pajak kendaraan bermotor di desa Rantau Alai khususnya dusun Tanjung di tahun 2017.

Manfaat penelitian ini adalah sebagai berikut:

1) Manfaat teoritis

Penelitian ini diharapkan memberikan wawasan kepada pembaca dan masyarakat umum bahwa motivasi dalam diri seorang wajib pajak berpengaruh terhadap kepatuhan wajib pajak tersebut untuk membayar pajak, khususnya pajak kendaraan bermotor.

2) Manfaat praktis

a. Bagi pemerintah daerah Diharapkan penelitian ini dapat dijadikan sebagai bahan masukan bagi Dinas Pendapatan dan Pengelolaan Aset Daerah Kabupaten 
Merangin dan instansi yang terkait guna meningkatkan Pajak Kendaraan Bermotor di Kabupaten Merangin di masa yang akan datang.

b. Bagi Peneliti Lain Menjadi bahan referensi bagi peneliti yang ingin meneliti tentang objek penelitian yang sejenis dengan penelitian, serta sebagai tambahan wawasan bagi peneliti mengenai pengaruh motivasi dan kontribusi pajak kendaraan bermotor untuk daerah.

\section{METODE PENELITIAN}

Metode yang digunakan dalam penelitian ini adalah metode kuantitatif korelasional, yaitu untuk mengetahui seberapa jauh pengaruh atau hubungan antara variabel $\mathrm{X}$ terhadap variabel Y berdasarkan koefisien dan korelasi. Populasi dalam penelitian ini adalah Wajib Pajak Kendaraan Bermotor warga Desa Rantau Alai khususnya dusun Tanjung yang berjumlah 117 orang. Sementara itu, sampel yang diteliti pada penelitian ini sebanyak 90 orang.

Teknik pengumpulan data dalam penelitian ini terdiri dari dua jenis, yakni data primer yaitu dengan menggunakan angket, dan data sekunder yakni menggunakan dokumentasi. Dalam penelitian ini, instrumen yang yang peneliti gunakan ialah metode angket (kuesioner) dan metode dokumentasi. Metode angket

untuk mengungkapkan pengaruh pengetahuan wajib pajak tentang perpajakan terhadap kepatuhan wajib pajak membayar pajak kendaraan bermotor di desa Rantau Alai khususnya dusun Tanjung di tahun 2017, dan metode dokumentasi digunakan untuk pengumpulan data berupa STNK kendaraan bermotor dalam bentuk foto sebagai bukti bahwa warga desa Rantau Alai patuh membayar pajak. Instrumen penelitian ini dilakukan dengan melakukan uji coba angket dengan menggunakan uji validitas variabel pengetahuan wajib pajak 17 butir pertanyaan yang valid dan variabel kepatuhan wajib pajak 16 butir pertanyaan yang valid. Pada uji reliabilitas diketahui hasil variabel $\mathrm{x}$ 0,866 dan variabel y 0,848 . Ini berarti bahwa item tersebut memiliki nilai lebih tinggi dari pada rtabel $(>0,361)$. Maka ditarik kesimpulan bahwa angket tersebut reliabel dan dapat digunakan untuk penelitian.

Teknik analisa data pada penelitian ini dilakukan dengan beberapa tahapan antara lain Uji Asumsi Klasik (Uji Normalitas dan Uji Linearitas) dan uji hipotesis (Uji Regresi Linear Sederhana dan Uji t).

\section{HASIL DAN PEMBAHASAN}

Pengetahuan wajib pajak tentang perpajakan menjadi salah satu penentu bagi masyarakat untuk patuh membayar pajak kendaraan bermotor yang mereka miliki. Pengetahuan wajib pajak tersebut diperoleh melalui pendidikan formal, pelatihan, atau sosialisasi. Adapun indikator seorang wajib pajak mengetahui tentang perpajakan yaitu (a) pengetahuan mengenai batas waktu pembayaran dan pelaporan, (b) pengetahuan mengenai ketentuan umum dan tata cara perpajakan, dan (c) pengetahuan mengenai sistem perpajakan (Nur Hidayati dalam Fermatasari, 2015:3). Melalui pengetahuan tentang perpajakan yang tepat, diharapkan dapat menciptakan kepatuhan bagi warga untuk membayar pajak, khususnya pajak kendaraan bermotor.

Deskrifsi variabel penelitian kepatuhan wajib pajak membayar pajak.Untuk mengetahui kepatuhan wajib pajak menggunakan 16 item angket yang disebarkan pada 90 orang responden. Berdasarkan dari hasil distribusi frekuensi variabel kepatuhan wajib pajak 
membayar pajak diperoleh informasi rerata variabel kepatuhan wajib pajak dengan Tingkat Capaian Responden 125,9 dengan kriteria sangat baik.

Deskripsi variabel pengetahuan tentang perpajakan. Untuk mengetahui variable pengetahuan tentang perpajakan dengan menggunakan data angket penelitian yang terdiri dari 17 item angket yang diberikan kepada 90 orang responden masyarakat desa rantau alai khususnya desa dusun tanjung. Berdasarkan dari hasil distribusi frekuensi variabel pengetahuan tentang perpajakan diperoleh informasi rerata variabel $101,1 \%$ dengan kategori sangat baik.

Hasil uji asumsi klasik uji normalitas dan uji linearitas.

Tabel 1. Uji Normalitas

\begin{tabular}{llccl}
\hline No & Variabel & Sig & $@$ & Ket \\
\hline 1 & Pengetahuan perpajakan (X) & 0,404 & 0,05 & Normal \\
\hline 2 & Kepatuhan Membayar Pajak (Y) & 0,055 & 0,05 & Normal \\
\hline
\end{tabular}

Sumber: Data primer

Berdasarkan hasil uji normalitas pada tabel tersebut, diperoleh bahwa nilai uji normalitas data variabel pengetahuan wajib pajak $(\mathrm{X})$ sebesar 0,404 dan variabel kepatuhan wajib pajak (Y) sebesar 0,055. Dengan ketentuan $\alpha=0,05$, maka dapat di ambil kesimpulan bahwa sampel pada penelitan ini berdistribusi normal $(0,404>$

$0,05),(0,055>0,05)$. Oleh karena itu dapat disimpulkan bahwa data berdistribusi normal.

Tabel 2. Uji Linearitas

\begin{tabular}{ccc}
\hline Dimensi & Signifikasi & Keterangan \\
\hline Pengetahuan Perpajakan & 0,352 & Linier \\
\hline
\end{tabular}

Sumber: Data primer

Berdasarkan tabel di atas, diperoleh nilai probabilitas $0,352 \geq 0,05$, maka dapat disimpulkan bahwa ada hubungan yang linear antara variabel pengetahuan wajib pajak (X) dengan variabel kepatuhan wajib pajak (Y).

Hasil Uji hipotesis yaitu uji regresi linear sederhana dan uji t.

Tabel 3 Uji Regresi Linear Sederhana

\begin{tabular}{llll}
\hline Konstruksi & T hit & Sig & Keterangan \\
\hline Pengetahuan Perpajakan & 2,055 & 0.043 & Positif \\
\hline
\end{tabular}

\section{Sumber: Data primer}

Berdasarkan tabel di atas, diperoleh nilai $\mathrm{t}$ hitung variable $\mathrm{x}$ sebesar 2,055. Kemudian, berdasarkan tabel di atas juga diperoleh nila sig sebesar 0,043 $\leq 0,05$. Dengan nilai tersebut, maka dapat disimpulkan bahwa ada pengaruh antara pengetahuan wajib pajak (X) dengan variabel kepatuhan wajib pajak (Y). Dan uji t diperoleh nilai sig sebesar $0,043 \leq$ 
0,05. Dari hasil uji hipotesis ini dapat diketahui bahwa hipotesis pada penelitian ini telah terjawab, yakni Ho ditolak, Ha diterima.

\section{KESIMPULAN DAN SARAN}

Dari hasil analisa data pada penelitian ini, ada beberapa hal yang dapat disimpulkan:

1) Hasil uji $\mathrm{t}$ diperoleh nilai nilai sig $0,043 \leq 0,05$, maka peneliti menyimpulkan bahwa hipotesis pada penelitian ini telah terjawab, yakni Ho ditolak, Ha diterima.

2) Terdapat pengaruh yang signifikan antara pengetahuan wajib pajak terhadap kepatuhan wajib pajak membayar pajak kendaraan bermotor di desa Rantau Alai khususnya dusun Tanjung tahun 2017.

\section{DAFTAR RUJUKAN}

Damajanti, Anita. 2015. Pengaruh Pengetahuan Terhadap Kepatuhan Wajib Pajak Perorangan Di Kota Semarang. J. Dinamika Sosbud Volume 17 Nomor 2, Juni 2015: $12-28$.

Fermatasari, Dewi. 2015. Pengaruh Pengetahuan Pajak Dan Sanksi Pajak Terhadap Kepatuhan Wajib Pajak (Survey di Kantor Pelayanan Pajak Pratama Bandung Karees).

Mustaqiem. 2008. Pajak Daerah dalam Transisi Otonomi Daerah. Yogyakarta: FH UII Press.

Sulistiyono, Adincha Ayuvisda. 2012. Pengaruh Motivasi Terhadap Kepatuhan Wajib Pajak Dalam Membayar Pajak Penghasilan Orang Pribadi Usahawan (Studi di Sentra Produksi Manik-manik Desa Plumbongambang, Kecamatan Gudo, Kabupaten Jombang, Provinsi Jawa Timur). Surabaya: Fakultas Ekonomi Universitas Negeri Surabaya 